University of Nebraska - Lincoln

DigitalCommons@University of Nebraska - Lincoln

1998

\title{
Complementary Responses Between Feather Meal and Poultry By-Product Meal with or Without Ruminally Protected Methionine and Lysine in Growing Calves
}

\author{
M. J. Klemesrud \\ University of Nebraska - $\mathrm{Li}$ \\ Terry J. Klopfenstein \\ University of Nebraska-Lincoln, tklopfenstein1@unl.edu \\ Austin Lewis \\ University of Nebraska-Lincoln, alewis2@unl.edu
}

Follow this and additional works at: https://digitalcommons.unl.edu/animalscifacpub

Part of the Animal Sciences Commons

Klemesrud, M. J.; Klopfenstein, Terry J.; and Lewis, Austin, "Complementary Responses Between Feather Meal and Poultry By-Product Meal with or Without Ruminally Protected Methionine and Lysine in Growing Calves" (1998). Faculty Papers and Publications in Animal Science. 523.

https://digitalcommons.unl.edu/animalscifacpub/523

This Article is brought to you for free and open access by the Animal Science Department at DigitalCommons@University of Nebraska - Lincoln. It has been accepted for inclusion in Faculty Papers and Publications in Animal Science by an authorized administrator of DigitalCommons@University of Nebraska - Lincoln. 


\title{
Complementary Responses Between Feather Meal and Poultry By-Product Meal with or Without Ruminally Protected Methionine and Lysine in Growing Calves ${ }^{1}$
}

\author{
M. J. Klemesrud, T. J. Klopfenstein², and A. J. Lewis \\ Department of Animal Science, University of Nebraska, Lincoln 68503-0908
}

\begin{abstract}
We evaluated feather meal (FTH) and poultry by-product meal (PBM) as complementary protein sources for growing calves. In a replicated 84-d growth trial, individually fed steer calves ( $\mathrm{n}=$ 120; $252 \pm 24 \mathrm{~kg}$ ) were supplemented with urea or with graded levels of soybean meal (SBM), FTH, PBM, or 2/3 FTH:1/3 PBM (CP basis). Protein efficiency, calculated as gain above the urea control vs natural protein intake using the sloperatio technique, was greater for $\mathrm{FTH}$ than for SBM, PBM, and $2 / 3$ $\mathrm{FTH}: 1 / 3$ PBM $(\mathrm{P}<.10)$. Addition of ruminally protected methionine and lysine did not affect protein efficiency $(P>.30)$ for $F T H, P B M$, or $2 / 3 F T H: 1 / 3$ PBM. Even though true protein digestibility in the
\end{abstract}

gastrointestinal tract in a trial with lambs was similar ( P > .15) for FTH (83.1\%) and PBM (91.2\%), escape protein was greater for FTH (66.8\%) than for PBM (43.6\%). Analyses were conducted to estimate intestinal flow of amino acids relative to requirements for live animal gain, and no obvious amino acid deficiencies were present. The lack of a response in protein efficiency to ruminally protected methionine and lysine suggests that FTH and PBM are adequate in these amino acids. Although FTH and PBM are excellent sources of metabolizable protein, there was no complementary response in protein efficiency between them.

Key Words: Beef Cattle, Feather Meal, Poultry Byproducts, Proteins, Amino Acids

@1998 American Society of Animal Science. All rights reserved.

J. Anim. Sci. 1998. 76:1970-1975

\section{Introduction}

Complementary responses between blood meal (BM) and feather meal (FTH; Goedeken et al., 1990a,b; Blasi, et al. 1991) are likely a result of improved ratios among limiting amino acids. Blood meal is high in lysine, and FTH is high in sulfur amino acids. Meat and bone meal ( $\mathbf{M B M}$ ), also a good source of lysine, showed no complementary response with FTH (Gibb et al., 1992). Even though methionine has been reported to be the first-limiting amino acid in MBM (Klemesrud et al., 1997b), sulfur amino acids in FTH are primarily cystine with very little methionine. Although cystine may meet over $50 \%$ of the sulfur amino acid requirement (Ahmed and Bergen, 1983), there remains a requirement for methionine (Reis et al., 1973). Likewise, a requirement for lysine has been demonstrated in cattle (Burris et al., 1976; Hill et al., 1980).

\footnotetext{
${ }^{1}$ Published with the approval of the director as paper no. 12003 , journal series, Nebraska Agric. Res. Div.

${ }^{2}$ To whom correspondence should be addressed.

Received August 21, 1997.

Accepted March 22, 1998.
}

Steers fed poultry by-product meal (PBM), a rendered by-product that is similar to MBM, achieved protein efficiencies greater than those in steers fed MBM (Klemesrud et al., 1997a), probably because of its higher methionine and lysine content. Research combining FTH and PBM was conducted to determine the complementary effects on protein efficiency. A second objective was to establish whether methionine and lysine limit growth in $\mathrm{FTH}$ - or PBM-supplemented calves.

\section{Materials and Methods}

Growth Trial. A replicated calf growth trial was conducted using 120 medium-framed crossbred beef steers ( $252 \pm 24 \mathrm{~kg}$ ) that were individually fed diets of $44 \%$ sorghum silage (7.1\% CP, $68 \%$ TDN), $44 \%$ corncobs (2.3\% CP, $48 \%$ TDN ), and $12 \%$ supplement (DM basis, Table 1). Steers were assigned randomly to treatment and level of treatment protein. Protein source in the supplement made up the treatments, which consisted of 1 ) urea (control); 2 ) soybean meal (SBM); 3) FTH; 4) PBM; 5) FTH:PBM (67:33 mix on a CP basis); 6) FTH plus ruminally protected methionine and lysine (FTH + ML) to supply an 
Table 1. Supplement composition, steer growth trial ${ }^{\mathrm{a}}$

\begin{tabular}{|c|c|c|c|c|c|c|c|c|}
\hline \multirow[b]{2}{*}{ Ingredient } & \multicolumn{8}{|c|}{ Treatment } \\
\hline & Urea & $\mathrm{SBM}^{\mathrm{b}}$ & $\mathrm{FTH}^{\mathrm{b}}$ & $\mathrm{PBM}^{\mathrm{b}}$ & $\begin{array}{l}\text { FTH: } \\
\text { PBM }^{\text {b }}\end{array}$ & $\begin{array}{l}\text { FTH } \\
+ \text { ML }^{b}\end{array}$ & $\begin{array}{l}\text { PBM } \\
+M^{b}\end{array}$ & $\begin{array}{c}\text { FTH:PBM } \\
+M L^{b}\end{array}$ \\
\hline Feather meal & - & - & 54.00 & - & 36.67 & 54.00 & - & 36.67 \\
\hline Poultry by-product & - & - & - & 87.50 & 27.87 & - & 87.50 & 27.87 \\
\hline Soybean meal & - & 85.00 & - & - & - & - & - & - \\
\hline Soyhulls & 72.63 & - & 34.34 & 7.54 & 27.17 & 33.33 & 6.26 & 26.07 \\
\hline Urea & 15.16 & 3.71 & - & - & - & - & - & - \\
\hline Smartamine $\mathrm{M}^{\circledR C}$ & - & - & - & - & - & .22 & .22 & .22 \\
\hline Smartamine $\mathrm{ML}^{\circledR \mathrm{d}}$ & - & - & - & - & - & .79 & 1.06 & .88 \\
\hline Dicalcium phosphate & 7.25 & 5.00 & 5.92 & - & 3.33 & 5.92 & - & 3.33 \\
\hline Limestone & - & 1.33 & .78 & - & - & .78 & - & - \\
\hline Salt & 2.50 & 2.50 & 2.50 & 2.50 & 2.50 & 2.50 & 2.50 & 2.50 \\
\hline Ammonium sulfate & 1.67 & 1.67 & 1.67 & 1.67 & 1.67 & 1.67 & 1.67 & 1.67 \\
\hline Trace minerals ${ }^{\mathrm{e}}$ & .42 & .42 & .42 & .42 & .42 & .42 & .42 & .42 \\
\hline Vitamins $^{f}$ & .25 & .25 & .25 & .25 & .25 & .25 & .25 & .25 \\
\hline Selenium 9 & .12 & .12 & .12 & .12 & .12 & .12 & .12 & .12 \\
\hline
\end{tabular}

\footnotetext{
a Values expressed as percentage of DM. Supplement intake was at $12 \%$ of DMI.

bSoybean meal (SBM); feather meal (FTH); poultry by-product meal (PBM); feather meal:poultry by-product meal combination (FTH: PBM, 67:33 on a CP basis); and FTH, PBM, and FTH:PBM with methionine and lysine (ML). Each supplement was mixed at feeding with the urea supplement to provide incremental levels of each test protein source. The levels fed of each test protein source were $20,30,40,50$, or $60 \%$ of the total supplemental protein; the urea supplement made up the remainder.

${ }^{\mathrm{C}} 70 \%$ methionine, Rhône-Poulenc Animal Nutrition, Atlanta, GA.

d $15 \%$ methionine, $50 \%$ lysine, Rhône-Poulenc Animal Nutrition, Atlanta, GA.

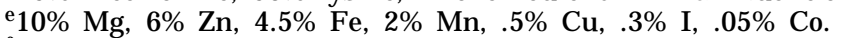

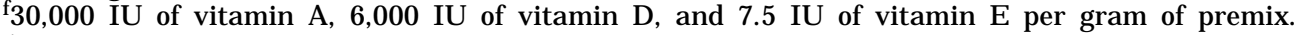

gPremix contained $.06 \%$ selenium.
}

additional $2.7 \mathrm{~g}$ of methionine and $4.0 \mathrm{~g}$ of lysine per kilogram of supplement; 7) PBM plus ruminally protected methionine and lysine (PBM + $\mathbf{M L}$ ) to supply an additional $3.1 \mathrm{~g}$ of methionine and $5.3 \mathrm{~g}$ of lysine per kilogram of supplement; 8) FTH:PBM (67: $33 \mathrm{mix}$ on a CP basis) plus ruminally protected methionine and lysine (FTH:PBM + ML) to supply an additional $2.8 \mathrm{~g}$ of methionine and $4.4 \mathrm{~g}$ of lysine per kilogram of supplement.

Each protein source was fed at five levels to supply incremental levels of natural protein. These levels were $20,30,40,50$, or $60 \%$ of the supplemental CP, and urea supplied the remainder. Therefore, regardless of the assigned level, all steers consumed a diet containing $11.0 \% \mathrm{CP}$ (DM basis). Steers were individually fed, at an equal percentage of body weight, once daily with Calan electronic gates (American Calan, Northwood, NH). The DM fed as a percentage of BW fed was adjusted as needed to minimize orts while maintaining intake near ad libitum. Average DMI was $2.08 \%$ of BW.

Weight data were collected every 28 d before feeding, and intakes were recalculated based on current weights. Weights were taken on three consecutive days at the beginning, d 56, and end of the 84-d trial. Efficiency of protein utilization was determined for each treatment using the sloperatio technique (Klopfenstein et al., 1985) with the ureasupplemented steers as the control. Protein efficiencies, calculated as the units of gain obtained relative to the urea control steers per unit of test protein consumed relative to the urea control diet, were determined for each treatment using the NLIN procedure of SAS (1985). Slopes (protein efficiency) were compared statistically using a two-tailed t-test (Steel and Torrie, 1980).

Digestion Study. Twenty-one crossbred wether lambs $(32.7 \pm 3.7 \mathrm{~kg})$ housed in individual metabolism crates were fed a basal diet (Table 2) containing ensiled corncobs and alfalfa pellets. This basal diet was fed to all lambs at $2.0 \%$ of BW (DM basis) throughout the trial. This maintenance diet was balanced to provide a minimum of $10 \% \mathrm{CP}, 52 \%$ TDN, .42\% Ca, and .18\% P. Urea was included in the

Table 2. Basal diet, lamb digestion trial

\begin{tabular}{lc}
\hline \hline Ingredient & $\%$, DM \\
\hline Ensiled corncobs & 72.70 \\
Alfalfa pellets & 15.00 \\
Ground corn & 10.00 \\
Urea & 1.48 \\
Dicalcium phosphate & .26 \\
Salt & .30 \\
Ammonium sulfate & .17 \\
Trace minerals $^{\mathrm{a}}$ & .04 \\
Vitamins $^{\mathrm{b}}$ & .03 \\
Selenium $^{\mathrm{c}}$ & .02
\end{tabular}

${ }^{a}$ Contains $10 \% \mathrm{Mg}, 6 \% \mathrm{Zn}, 4.5 \% \mathrm{Fe}, 2 \% \mathrm{Mn}, .5 \% \mathrm{Cu}$, and . $3 \% \mathrm{I}$. b 15,000 IU vitamin A, 3,000 IU vitamin D, and 3.75 IU vitamin E per gram of premix.

CPremix contains $.06 \%$ selenium. 
basal diet to ensure that ruminal $\mathrm{NH}_{3}$ was not limiting digestion and provided $44 \%$ of the basal dietary $\mathrm{CP}$.

The study consisted of a 14-d adaptation period and a 7-d fecal collection period. Lambs were assigned randomly to receive either $\mathrm{FTH}, \mathrm{PBM}, \mathrm{SBM}$, or an unsupplemented control. Treatments contained five lambs each, with the exception of the unsupplemented control, which contained six lambs. Supplemental protein sources were fed at $3.75 \%$ of the basal diet DMI as units of additional CP. Therefore, the supplemental DM in addition to the basal diet was dependent on the $\mathrm{CP}$ content of the treatment protein source. All diets containing treatment proteins were isonitrogenous and contained $13.75 \% \mathrm{CP}$, and the unsupplemented control diet contained $10 \%$ CP. Treatment protein sources were individually weighed and hand-mixed into the basal diet daily at the time of feeding.

Lambs were weighed before the trial to enable feeding diets on an equal percentage of BW. Lambs were fitted with fecal collection bags to allow for total fecal collection. Feces were collected daily and weighed, and a $10 \%$ subsample was taken. Subsamples were composited by lamb for the 7-d collection period. Feed, feces, and orts were oven-dried $\left(60^{\circ} \mathrm{C}\right)$ and analyzed for DM and CP content (AOAC, 1990). True protein digestibility was calculated by difference from unsupplemented-control lambs as outlined by Blasi et al. (1991). Results were analyzed as a completely randomized design using the GLM procedure of SAS (1985). Least significant differences (SAS, 1985) were used to separate treatment means.

In Situ Study. Samples of FTH and PBM were incubated in situ to determine escape protein (Wilkerson et al., 1995). Approximately $4 \mathrm{~g}$ of each source was placed in each of four Dacron bags $(10 \times 20 \mathrm{~cm}$; $50 \mu \mathrm{m}$ pore size; Ankom, Fairport, NY). Each bag was sealed by wrapping the top around a \#8 rubber stopper and securing it with a \#18 rubber band. The bag was then folded over the rubber band and a second rubber band was added. Sample bags were placed in a polyester bag $36 \times 42 \mathrm{~cm}$ made of mesh material and closed with a nylon zipper. To facilitate hydration, all bags were soaked in $39^{\circ} \mathrm{C}$ water for 20 min prior to placement in the liquid phase of the ruminal ventral sac of a ruminally cannulated crossbred steer (534 $\mathrm{kg}$ ) maintained on a grass hay diet.

Following $12 \mathrm{~h}$ of ruminal incubation (Wilkerson et al., 1993), bags were removed from the rumen and washed by hand until the rinse water was clear. Total N (AOAC, 1990) was determined before and after ruminal incubation to estimate the amount of ruminal escape protein. Least significant differences (SAS, 1985) were used to separate treatment means. Additionally, PBM was analyzed for ash content (AOAC, 1990) as an estimate of the amount of bone.

Residue remaining after ruminal incubation was composited by protein source and analyzed for amino acid content to estimate intestinal flow of amino acids. Residue was hydrolyzed in $6 \mathrm{~N} \mathrm{HCl}$, and amino acid content of hydrolyzates was determined by ionexchange chromatography (AOAC, 1990). Separate samples were oxidized with performic acid for analysis of cystine and methionine (AOAC, 1990). A separate analysis for tryptophan was conducted using the procedure of Lewis et al. (1976) modified for manual analysis. All analyses were conducted in duplicate and averaged for calculation of intestinal amino acid flows.

\section{Results and Discussion}

Growth Trial. Gain and feed efficiency of steers were increased $(P<.05)$ by all supplements compared with the urea control (Table 3 ). The increase in gain presumably resulted from the additional metabolizable protein (MP) supplied by these sources. The increase in gain/feed was caused by the increase in gain because daily feed intake was equal for all treatments. Feather meal protein was utilized more efficiently $(\mathrm{P}<.10)$ than PBM, FTH:PBM, or SBM protein for $\mathrm{BW}$ gain (Figure 1). The difference in escape protein likely accounted for much of this

Table 3. Protein response of steer calves fed urea, soybean meal (SBM), feather meal (FTH), and poultry by-product meal (PBM), with or without supplemental methionine and lysine (ML)

\begin{tabular}{|c|c|c|c|c|c|c|c|c|c|}
\hline Item $^{a}$ & Urea & $\mathrm{SBM}^{\mathrm{b}}$ & $\mathrm{FTH}^{\mathrm{b}}$ & $\mathrm{PBM}^{\mathrm{b}}$ & $\begin{array}{l}\text { FTH: } \\
\text { PBM }^{\text {b }}\end{array}$ & $\begin{array}{l}\text { FTH } \\
+ \text { ML }^{b}\end{array}$ & $\begin{array}{l}\text { PBM } \\
+ \text { HL }^{b}\end{array}$ & $\begin{array}{c}\mathrm{FTH}: \text { PBM } \\
+\mathrm{ML}^{\mathrm{b}}\end{array}$ & SEM \\
\hline Daily DMI, \% of BW & 2.08 & 2.08 & 2.08 & 2.08 & 2.08 & 2.08 & 2.08 & 2.08 & \\
\hline Daily gain, kg & $.24^{c}$ & $.34^{\mathrm{d}}$ & $.44^{\mathrm{d}}$ & $.43^{\mathrm{d}}$ & $.42^{\mathrm{d}}$ & $.43^{\mathrm{d}}$ & $.42^{\mathrm{d}}$ & $.44^{d}$ & .02 \\
\hline Gain:feed & $.044^{\mathrm{C}}$ & $.064^{\mathrm{d}}$ & $.080^{\mathrm{d}}$ & $.079^{\mathrm{d}}$ & $.078^{\mathrm{d}}$ & $.080^{\mathrm{d}}$ & $.077^{d}$ & $.082^{\mathrm{d}}$ & .006 \\
\hline
\end{tabular}

aExpressed as the average of levels fed.

bSoybean meal (SBM); feather meal (FTH); poultry by-product meal (PBM); and feather meal:poultry by-product meal combination (FTH:PBM, 67:33 on a CP basis); and FTH, PBM, and FTH:PBM with methionine and lysine (ML). Each supplement was mixed at feeding with the urea supplement to provide incremental levels of each test protein source. The levels fed of each test protein source were $20,30,40$, 50 , and $60 \%$ of the total supplemental protein; the urea supplement made up the remainder.

c,d Means within a row with different superscripts differ $(P<.05)$. 


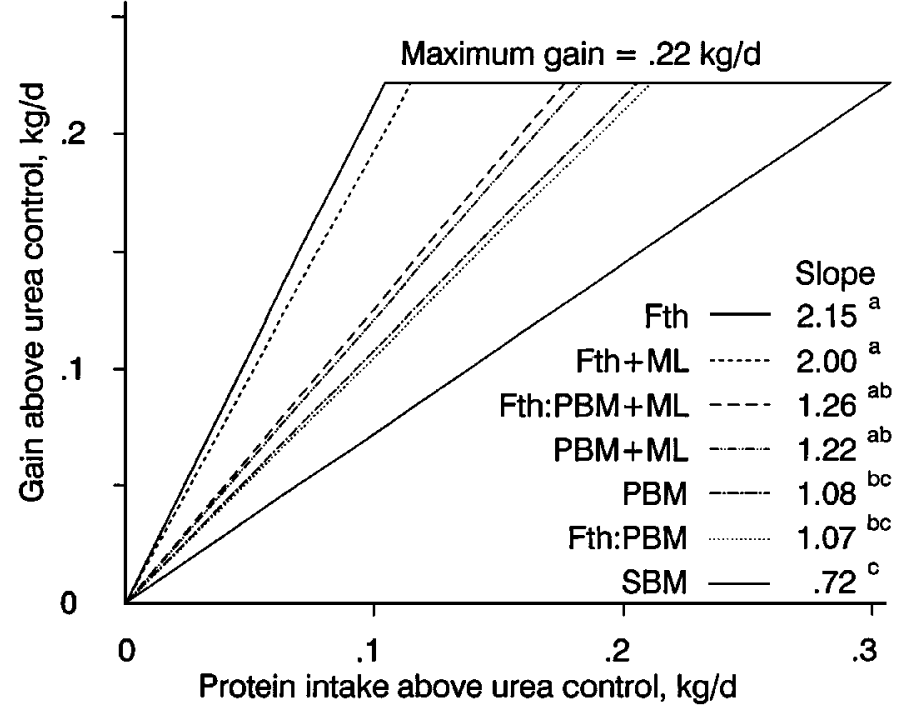

Figure 1. Regression of daily supplemental natural protein intake against daily gain above urea control. Resulting values (slopes) represent the protein efficiencies. Standard errors of the slopes are .18, .68, .23, .23, $.59, .34$, and .32 for soybean meal (SBM), feather meal (Fth), poultry by-product meal (PBM), feather meal: poultry by-product meal (Fth:PBM), feather meal plus methionine and lysine (Fth $+\mathrm{ML}$ ), poultry by-product meal plus methionine and lysine (PBM + ML), and feather meal:poultry by-product meal plus methionine and lysine (Fth:PBM + ML). Values with different superscripts differ $(P<.10)$.

difference. Maximal gain, determined using the NLIN procedure of SAS (1985) was .46 kg/d, or .22 kg/d greater than the gain obtained by the urea control steers.

Klemesrud et al. (1997b) reported an increase in protein efficiency in MBM with methionine supplementation, indicating that protected amino acids were available for digestion and absorption postruminally. Addition of methionine and lysine to PBM and FTH:PBM did not increase protein efficiency $(P>.30$, Table 4). Klemesrud et al. (1997a) reported that PBM contained higher levels of methionine than did $M B M$. A nonsignificant response to methionine and lysine supplementation suggests that PBM contained nearly adequate levels of methionine and lysine.

Blasi et al. (1991) and Goedeken et al. (1990b) theorized that the positive associative effect between $\mathrm{BM}$ and FTH was the result of the high lysine content of the BM complementing the high sulfur amino acid content of the FTH. Although an excellent source of sulfur amino acids, FTH contributes primarily cystine rather than methionine. Addition of methionine and lysine, however, failed to increase protein efficiency for $\mathrm{FTH}$, which suggests that $\mathrm{FTH}$ also contains adequate methionine and lysine.

A complementary effect between FTH and PBM would have resulted in a protein efficiency greater
Table 4. Effect of methionine and lysine supplementation on efficiency of protein utilization

\begin{tabular}{lcc}
\hline \hline & \multicolumn{2}{c}{ Protein efficiency $^{\mathrm{a}}$} \\
\cline { 2 - 3 } & $\begin{array}{c}\text { Without } \\
\text { methionine and } \\
\text { Iysine }\end{array}$ & $\begin{array}{c}\text { With } \\
\text { methionine } \\
\text { and Iysine }\end{array}$ \\
\hline Protein source & $.71^{\mathrm{d}} \pm .18$ & - \\
$\begin{array}{l}\text { Soybean meal } \\
\text { Feather meal }\end{array}$ & $2.15^{\mathrm{c}} \pm .68$ & $2.00 \pm .59$ \\
Poultry by-product & $1.07^{\mathrm{d}} \pm .23$ & $1.21 \pm .34$ \\
meal & $1.06^{\mathrm{d}} \pm .23$ & $1.25 \pm .32$ \\
FTH:PBM & b &
\end{tabular}

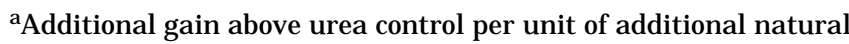
protein fed (mean $\pm S E)$. No protein $\times$ methionine and lysine interaction $(P>.30)$.

${ }^{b}$ Feather meal: poultry by-product meal, 67.33 on a CP basis.

$c$, dValues within a column with different superscripts differ $(P<$ $.10)$.

than the weighted average of the two (1.79). No complementary effect was observed because the protein efficiency for the combination was 1.06, equal to that of PBM (Table 4). The lack of a positive associative effect between FTH and PBM suggests both contain inadequate levels of a limiting amino acid(s) or that neither has a limiting amino acid.

Digestion and In Situ Study. There were no differences in true supplemental $\mathrm{N}$ digestibility $(\mathrm{P}>$ .15) among SBM, FTH, or PBM (Table 5). Numerically, PBM had the highest true $\mathrm{N}$ digestibility $(91.2 \%)$, and FTH had the lowest (83.2\%). Although there have been reports of poor $\mathrm{N}$ digestibilities of FTH in swine (Knabe et al., 1989), there are few reports of low protein digestibilities for ruminants. Goedeken et al. (1990b) and Blasi et al. (1991) found that FTH protein, calculated by difference from a urea control, was digested less extensively than either BM or SBM protein, but both reports indicated a true $\mathrm{N}$ digestibility $>86 \%$. Klemesrud et al. (1997a) found that true $\mathrm{N}$ digestibility for PBM sources, calculated by difference from urea, ranged from 84.6 to $93.2 \%$.

Table 5. Crude protein digestibility of test proteins by lambs

\begin{tabular}{lcc}
\hline \hline & $\begin{array}{c}\text { Apparent diet } \\
\text { CP }\end{array}$ & $\begin{array}{c}\text { True } \\
\text { supplement CP } \\
\text { Item }\end{array}$ \\
\hline Unsestibility, \% & digestibility, \% \\
\hline Soybean meal & $67.3^{b}$ & - \\
Feather meal & $73.3^{c}$ & 91.1 \\
Poultry by-product meal & $71.3^{c}$ & 83.1 \\
SEM & $73.3^{c}$ & 91.2 \\
\hline
\end{tabular}

${ }^{\text {a }}$ Calculated by difference from apparent $\mathrm{CP}$ digestibility of unsupplemented control. No significant difference between treatments $(\mathrm{P}>.15)$. $.01)$

b,c Means within a column with different superscripts differ $(P<$ 
Results from the present trial indicate that all protein sources were highly digestible.

The feather meal used for these trials contained 81.8\% CP, whereas PBM contained $53.9 \% \mathrm{CP}$ and $21.7 \%$ ash (DM basis; Table 6). Escape protein, expressed as a percentage of the $\mathrm{CP}$ remaining after $12 \mathrm{~h}$ of ruminal incubation, was greater $(P<.01)$ for FTH (66.8\%) than for PBM (43.6\%). Escape protein for FTH was similar to values reported by Gibb et al. (1992), whereas escape protein for PBM was similar to values reported by Klemesrud et al. (1997a).

Amino acid profiles after in situ ruminal incubation were determined (Table 6) for FTH and PBM and were used to predict flow of amino acids to the small intestine (Table 7). The amount of MP and metabolizable amino acids supplied by each treatment were calculated using the equations of Goedeken et al. (1990a) that account for digestible escape protein from the supplement, digestible escape protein from the basal diet, and microbial protein production. Ruminal microbial amino acid absorption from the small intestine was based on the conversion of $10.4 \%$ of the TDN to digestible microbial CP (Burroughs et al., 1974). Amino acid content of microbial protein was estimated by Goedeken et al. (1990a) by feeding a diet containing only nonprotein $\mathrm{N}$ and analyzing whole ruminal contents. Escape protein and amino acid composition for basal diet ingredients were reported by Gibb et al. (1992). Calculations for amino acids supplied were based on a daily DMI of $2.08 \%$ of BW for steers weighing $269 \mathrm{~kg}$ (average midtrial BW). Treatments were compared at an equal level of protein intake. The level selected was $104 \mathrm{~g}$ of natural protein intake, which corresponds to the break point
Table 6. Crude protein, escape proteina, and amino acid content ${ }^{\mathrm{a}}$ after $12 \mathrm{~h}$ in situ incubation of feather meal (FTH) and poultry by-product meal (PBM)

\begin{tabular}{lcc}
\hline \hline Item & FTH & PBM \\
\hline Crude protein, \% & 81.8 & 53.9 \\
Ash, \% & - & 21.7 \\
N escape, \% & 66.8 & 43.6 \\
Arginine & 7.8 & 9.6 \\
Cystine & 4.8 & 1.4 \\
Histidine & 1.4 & 2.7 \\
Isoleucine & 5.3 & 5.0 \\
Leucine & 9.6 & 8.7 \\
Lysine & 2.7 & 8.0 \\
Methionine & .7 & 2.2 \\
Phenylalanine & 5.7 & 4.8 \\
Threonine & 4.7 & 4.7 \\
Valine & 8.6 & 6.1 \\
Tryptophan & .4 & .5 \\
\hline
\end{tabular}

${ }^{\mathrm{a}} \mathrm{E}$ xpressed as a percentage of $\mathrm{CP}$ remaining after a 12 -h incubation in situ.

where maximum gain was achieved for the most efficiently used protein source, FTH.

The total MP and amino acids supplied to the small intestine (Table 7) were compared to the requirements estimated by Wilkerson et al. (1993), where the MP requirement was $3.8 \times \mathrm{BW} .75$ (grams/day, where BW is expressed as kilograms) for maintenance and $305 \mathrm{~g} / \mathrm{kg}$ of live weight gain. At an equal level of protein intake, FTH treatments provided MP equal to the requirement, whereas other supplements provided less MP. This difference reflected the greater escape protein for feather meal. All treatments provided more MP than the urea control, a result of the differences in

Table 7. Estimated metabolizable protein and amino acids supplied by diet to the small intestine

\begin{tabular}{|c|c|c|c|c|c|c|c|c|c|}
\hline \multirow[b]{2}{*}{ Item } & \multicolumn{8}{|c|}{ Treatment } & \multirow[b]{2}{*}{ Wilkerson } \\
\hline & Urea & $\mathrm{SBM}^{\mathrm{b}}$ & $\mathrm{FTH}^{\mathrm{b}}$ & $\mathrm{PBM}^{\mathrm{b}}$ & $\begin{array}{l}\text { FTH: } \\
\text { PBM }^{b}\end{array}$ & $\underset{\mathrm{ML}^{\mathrm{b}}}{\mathrm{FTH}}+$ & $\underset{\mathrm{ML}^{\mathrm{b}}}{\mathrm{PBM}}+$ & $\begin{array}{l}\text { FTH:PBM } \\
+ \text { ML }^{b}\end{array}$ & \\
\hline Protein & 335 & 360 & 392 & 377 & 387 & 393 & 378 & 388 & 392 \\
\hline Histidine & 6.0 & 6.6 & 6.8 & 7.2 & 7.0 & 6.8 & 7.2 & 6.9 & 6.3 \\
\hline Isoleucine & 20.9 & 22.2 & 24.2 & 23.3 & 23.9 & 24.1 & 23.2 & 23.9 & 22.0 \\
\hline Leucine & 33.6 & 35.8 & 39.4 & 37.7 & 38.9 & 39.2 & 37.5 & 38.8 & 27.1 \\
\hline Lysine & 30.0 & 31.8 & 31.8 & 33.8 & 32.5 & 32.6 & 34.9 & 33.4 & 31.4 \\
\hline Methionine & 10.9 & 11.4 & 11.4 & 12.0 & 11.6 & 12.0 & 12.6 & 12.3 & 11.8 \\
\hline Phenylalanine & 21.2 & 21.7 & 23.8 & 22.6 & 23.4 & 23.7 & 22.5 & 23.4 & 15.3 \\
\hline Threonine & 24.5 & 25.9 & 27.5 & 26.9 & 27.3 & 27.4 & 26.8 & 27.3 & 20.4 \\
\hline Valine & 23.6 & 24.9 & 28.8 & 26.5 & 28.1 & 28.7 & 26.4 & 28.0 & 22.4 \\
\hline Tryptophan & 3.8 & 4.1 & 4.1 & 4.1 & 4.1 & 4.1 & 4.0 & 4.1 & 3.9 \\
\hline TSAA $^{d}$ & 20.0 & 21.4 & 23.3 & 21.8 & 22.9 & 23.9 & 22.4 & 23.5 & 22.8 \\
\hline
\end{tabular}

${ }^{a}$ Expressed as grams/day of metabolizable protein and amino acids flowing to the small intestine at an equal level of natural protein intake $(104 \mathrm{~g} / \mathrm{d})$

bSoybean meal (SBM); feather meal (FTH); poultry by-product meal (PBM); feather meal:poultry by-product meal combination (FTH: PBM, 67:33 on a CP basis); and FTH, PBM, and FTH:PBM with methionine and lysine (ML). Each supplement was mixed at feeding with the urea supplement to provide incremental levels of each test protein source. The levels fed of each test protein source were 20, 30, 40, 50, and $60 \%$ of the total supplemental protein; the urea supplement made up the remainder.

Wilkerson et al. (1993) requirements based on a $269-\mathrm{kg}$ animal that gains $.46 \mathrm{~kg} / \mathrm{d}(.22 \mathrm{~kg} / \mathrm{d}$ above the urea control).

dTotal sulfur amino acids (methionine + cystine). 
escape protein. Metabolizable protein supply seems to explain most of the differences in ADG and protein efficiency between treatments.

Lack of a complementary response between FTH and PBM suggests an amino acid deficiency; however, no obvious deficiencies were observed (Table 7). Feather meal is a poor source of histidine, whereas BM is an excellent source (Gibb et al., 1992), which may explain the complementary responses reported in their study between FTH and BM. Relative to beef muscle tissue, microbial protein is also low in histidine (Owens, 1986). Although they contain levels of histidine greater than those in FTH, MBM and PBM contain much less histidine than does BM, which may explain the lack of a complementary response between FTH and MBM (Gibb et al., 1992) or FTH and PBM if histidine is first-limiting.

Tryptophan concentrations suggest that FTH and PBM may be poor sources of this vital amino acid. Even though the requirement for tryptophan in growing cattle has been estimated at $1.0 \%$ of MP (Wilkerson et al., 1993), FTH and PBM proteins contain only .4 and .5\% tryptophan, respectively (Table 6). Gibb et al. (1992) concluded that tryptophan was not the first-limiting amino acid when MBM or combinations of MBM and FTH were fed. This is likely because methionine is the first-limiting amino acid in MBM (Klemesrud et al., 1997b). After the methionine requirement is met, the low levels of tryptophan in MBM may cause it to become the nextlimiting amino acid. Poultry by-product meal contained greater levels of methionine than did MBM but similar levels of tryptophan (Klemesrud et al., 1997a), suggesting that PBM may be first-limiting in tryptophan. Blood meal is also a good source of tryptophan (Gibb et al., 1992), which may explain the complementary responses observed between FTH and BM. The low levels of tryptophan in FTH, MBM, and PBM may explain the lack of a complementary response between FTH and MBM (Gibb et al., 1992) and FTH and PBM.

\section{Implications}

Adding feather meal and poultry by-product meal to diets of growing steers increased the metabolizable protein supplied and thereby increased protein efficiency. Neither methionine nor lysine was the firstlimiting amino acid when feather meal, poultry byproduct meal, or combinations of feather meal and poultry by-product meal were fed to growing cattle. There was no advantage in combining poultry byproduct meal with feather meal on protein efficiency.

\section{Literature Cited}

Ahmed, B. M., and W. G. Bergen. 1983. Methionine-cyst(e)ine relationship in steers. J. Anim. Sci. 57(Suppl. 1):110 (Abstr.).

AOAC. 1990. Official Methods of Analysis (15th Ed.). Association of Official Analytical Chemists, Arlington, VA.

Blasi, D. A., T. J . Klopfenstein, J . S. Drouillard, and M. H. Sindt. 1991. Hydrolysis time as a factor affecting the nutritive value of feather meal and feather meal-blood meal combinations for growing calves. J. Anim. Sci. 69:1272-1278.

Burris, W. R., J . A. Boling, N. W. Bradley, and A. W. Young. 1976. Abomasal lysine infusion in steers fed a urea supplemented diet. J . Anim. Sci. 42:699-705.

Burroughs, W., A. H. Trenkle, and R. L. Vetter. 1974. A system of protein evaluation for cattle and sheep involving metabolizable protein (amino acids) and urea fermentation potential of feedstuffs. Vet. Med. Small Anim. Clin. 69:713-722.

Gibb, D. J ., T. J . Klopfenstein, and M. H. Sindt. 1992. Combinations of rendered protein meals for growing calves. J . Anim. Sci. 70: 2581-2589.

Goedeken, F. K., T. J . Klopfenstein, R. A. Stock, and R. A. Britton. 1990a. Hydrolyzed feather meal as a protein source for growing calves. J. Anim. Sci. 68:2945-2953.

Goedeken, F. K., T. J . Klopfenstein, R. A. Stock, R. A. Britton, and M. H. Sindt. 1990b. Protein value of feather meal for ruminants as affected by blood additions. J. Anim. Sci. 68:2936-2944.

Hill, G. M., J. A. Boling, and N. W. Bradley. 1980. Postruminal lysine and methionine infusion in steers fed a urea-supplemented diet adequate in sulfur. J . Dairy Sci. 63:1242-1247.

Klemesrud, M. J ., T. J . Klopfenstein, A. J . Lewis, D. H. Shain, and D. W. Herold. 1997a. Limiting amino acids in meat and bone and poultry by-product meals. J. Anim. Sci. 75:3294-3300.

Klemesrud, M. J ., T. J . Klopfenstein, and A. J . Lewis. 1997b. Addition of ruminal escape methionine and lysine to meat and bone meal. J . Anim. Sci. 75:3301-3306.

Klopfenstein, T., R. Stock, and R. Britton. 1985. Relevance of bypass protein to cattle feeding. Prof. Anim. Sci. 1:27-31.

Knabe, D. A., D. C. LaRue, E. J. Gregg, G. M. Martinez, and T. D. Tanksley, J r. 1989. Apparent digestibility of nitrogen and amino acids in protein feedstuffs by growing pigs. J . Anim. Sci. 67:441-458.

Lewis, A. J ., P. J . Holden, R. C. Ewan, and D. R. Zimmerman. 1976. An automated fluorometric method for the measurement of tryptophan in plasma. J. Agric. Food Chem. 24:1081-1083.

Owens, F. N. 1986. Protein utilization in ruminants: Current concepts in formulating ruminant diets. Proc. Am. Feed Industry Assoc. Nutr. Symp., St. Louis, MO. pp 12-33.

Reis, P. J ., D. A. Tunks, and L. F. Sharry. 1973. Plasma amino acid patterns in sheep receiving abomasal infusions of methionine and cystine. Aust. J. Biol. Sci. 26:635-643.

SAS. 1985. SAS User's Guide: Statistics. SAS Inst. Inc., Cary, NC.

Steel, R.G.D., and J. H. Torrie. 1980. Principles and Procedures of Statistics: A Biometrical Approach (2nd Ed.). McGraw-Hill Book Co., New York.

Wilkerson, V. A., T. J . Klopfenstein, R. A. Britton, R. A. Stock, and P. S. Miller. 1993. Metabolizable protein and amino acid re quirements of growing cattle. J. Anim. Sci. 71:2777-2784.

Wilkerson, V. A., T. J. Klopfenstein, and W. W. Stroup. 1995. A collaborative study of in situ forage protein degradation. J. Anim. Sci. 73:583-588. 